\title{
AC 2009-609: ASSESSING THE IMPACT OF FAILURE CASE STUDIES ON THE CIVIL ENGINEERING AND ENGINEERING MECHANICS CURRICULUM: FINAL REPORT
}

Norb Delatte, Cleveland State University

Paul Bosela, Cleveland State University

Joshua Bagaka's, Cleveland State University

Rosemary Sutton, Cleveland State University 


\title{
Assessing the Impact of Failure Case Studies on the Civil Engineering and Engineering Mechanics Curriculum: Final Report
}

\begin{abstract}
This paper is the third and last in a series documenting work to assess the impact of the introduction of failure case studies into engineering mechanics and civil engineering courses. Results from surveys and focus groups of both students and faculty are presented, along with recommendations for improving assessment instruments and processes. The students enjoyed the case studies and believed that they contributed to learning the course material. The case studies stimulated their interest. Most faculty who had participated in the one-day case study workshop and who responded to the survey had made at least some use of the cases in their courses. The respondents that had used case studies believed that the benefits justified the cost.
\end{abstract}

\section{Introduction}

Over the past three years research has evaluated the impact of including failure case studies in specific civil engineering and engineering mechanics courses. The effect of the failure case studies on student learning has been assessed through surveys as well as focus groups, led by researchers from the College of Education and Human Services. The case studies were pilot tested in two courses, Strength of Materials (sophomore, engineering mechanics) and Construction Planning and Estimating (senior, civil engineering) over the course of several years. Preliminary results have been previously reported elsewhere ${ }^{1,2}$. The project results have also been presented at international conferences in Mumbai, India ${ }^{3}$, and London, United Kingdom ${ }^{4}$.

A series of faculty workshops were also carried out under this project. The workshop participants were primarily from U.S. civil engineering programs, but also included faculty in architectural, construction, and other engineering programs, and faculty from Canada and Ireland. The workshop materials included copies of case study technical papers along with a CD of PowerPoint presentations on individual case studies. The workshops were held in Cleveland (2006), Denver (2007), Pittsburgh (2008), and London (2008). Three workshops had also been carried out under an earlier NSF project. Findings from the workshops have been previously presented $^{5}$.

The final products of this project include a book and a web site. The failure case studies developed under this project and an earlier NSF-funded project have resulted in a book published by the American Society for Civil Engineers (ASCE) Press, Beyond Failure: Forensic Case Studies for Civil Engineers ${ }^{6}$. This book breaks down failure case studies into chapters arranged by engineering courses and topics.

Full and abbreviated versions of the case studies featured in the book, as well as some others, have also been assembled into a web site. This web site (http://matdl.org/failurecases/) is part of the Materials Digital Library, which is in turn a portal of the National Science Digital Library. 


\section{Project Description}

In a typical semester, two or three case studies are presented to the students, with class lectures and supplemental reading. These provide opportunities for in-depth class discussion not only about technical issues, but also about professional practice issues. Case study questions were included on homework assignments and examinations. A detailed project plan has been presented elsewhere ${ }^{1}$.

\section{Project Results}

In surveys and focus groups, students were asked specifically about the technical lessons learned, as well as their personal responses to the case studies. Survey questions linked student achievement to the $\mathrm{a}-\mathrm{k}$ ABET outcomes. Case studies are particularly useful for addressing the outcomes concerned with professional and ethical responsibility, global and societal context, life-long learning, and contemporary issues. The latter two outcomes may be addressed by discussing recent collapses, such as the Pittsburgh Convention Center or the Minneapolis I-35W Bridge.

Student survey responses from the spring 2007 and 2008 courses are presented in tables 1 and 2. Tables 1 and 2 suggest which outcomes may be considered to be strongly supported by the failure case studies. The scale ranged from 1 - strongly disagree to 5 - strongly agree.

In 2007, the students in both classes rated ability to apply knowledge of mathematics, science, and engineering; understanding of professional and ethical responsibility; and knowledge of contemporary issues at 4 or higher on average. The sophomore students also rated the broad education necessary to understand the impact of engineering solutions in a global and social context above 4. The senior students rated ability to function on multi-disciplinary teams; ability to identify, formulate, and solve engineering problems; recognition of the need for, and an ability to engage in life-long learning; and ability to use the techniques, skills, and modern engineering tools necessary for engineering practice at 4 or higher. All average results were 3.33 or higher. This suggests that the failure case studies can be important for enhancing learning of all ABET outcomes.

With the 2008 results, shown in Table 2 , the averages in both classes for ability to apply knowledge of mathematics, science, and engineering; understanding of professional and ethical responsibility; and knowledge of contemporary issues were all 3.81 or higher. All averages were 3.50 or higher.

The students were also asked to rate the relative contributions of the textbook, lectures, homework, projects (if any), exams, and the case studies to their interest and understanding of the course material. These results are shown in tables 3 and 4. In 2007, case studies were ranked at 4.33 (highest) and 3.88 (second highest) for interest by the sophomores and the seniors respectively, and at 4.0 for understanding (tied for third highest, highest). These show strong reinforcement of the specific course technical material. The 2008 results, shown in table 4 , ranked case studies at 4.04 for sophomores and 4.50 for seniors for contribution to interest. 
These were the highest values. 2008 contributions to understanding were 3.73 for sophomores and 4.50 for seniors. The summary statistics indicate that students benefited most from case studies in the following ways:

1. Making the course more interesting.

2. Helping students broaden their understanding of the impact of engineering solutions in global and social contexts.

3. Making students aware of their professional and ethical responsibility.

4. Increasing students' ability to apply knowledge of engineering to real life situations.

Table 1: Student Survey Responses related to ABET Outcomes (Spring 2007)

\begin{tabular}{|c|c|c|c|c|c|c|c|c|}
\hline Course & $\begin{array}{l}\text { Strel } \\
\text { ESC }\end{array}$ & $\begin{array}{l}\text { gth of } \\
211\end{array}$ & Materi & & $\begin{array}{l}\text { Cons } \\
\text { and } \mathbf{E}\end{array}$ & $\begin{array}{l}\text { ruction } \\
\text { stimati }\end{array}$ & $\begin{array}{l}\text { Plann } \\
\text { lg CV }\end{array}$ & E 403 \\
\hline The case studies contributed to: & Ave & SD & High & Low & Ave & SD & High & Low \\
\hline $\begin{array}{l}\text { my ability to apply knowledge of } \\
\text { mathematics, science, and } \\
\text { engineering; }\end{array}$ & 4.33 & 0.71 & 5 & 3 & 4.00 & 0.53 & 5 & 3 \\
\hline $\begin{array}{l}\text { my ability to design and conduct } \\
\text { experiments, as well as to analyze } \\
\text { and interpret data }\end{array}$ & 3.67 & 0.71 & 5 & 3 & 3.75 & 0.46 & 4 & 3 \\
\hline $\begin{array}{l}\text { my ability to design a system, } \\
\text { component, or process to meet } \\
\text { desired needs, using the principles } \\
\text { of equilibrium; }\end{array}$ & 3.78 & 0.67 & 5 & 3 & 3.75 & 0.89 & 5 & 3 \\
\hline $\begin{array}{l}\text { my ability to function on multi- } \\
\text { disciplinary teams }\end{array}$ & 3.33 & 0.50 & 4 & 3 & 4.00 & 0.76 & 5 & 3 \\
\hline $\begin{array}{l}\text { my ability to identify, formulate, } \\
\text { and solve engineering problems; }\end{array}$ & 3.78 & 0.83 & 5 & 3 & 4.25 & 0.46 & 5 & 4 \\
\hline $\begin{array}{l}\text { my understanding of professional } \\
\text { and ethical responsibility }\end{array}$ & 4.33 & 1.12 & 5 & 2 & 4.75 & 0.46 & 5 & 4 \\
\hline $\begin{array}{l}\text { my ability to communicate my } \\
\text { problem solutions effectively; }\end{array}$ & 3.56 & 0.88 & 5 & 2 & 3.88 & 0.35 & 4 & 3 \\
\hline $\begin{array}{l}\text { the broad education necessary to } \\
\text { understand the impact of } \\
\text { engineering solutions in a global } \\
\text { and social context }\end{array}$ & 4.22 & 0.67 & 5 & 3 & 3.75 & 0.71 & 5 & 3 \\
\hline $\begin{array}{l}\text { my recognition of the need for, } \\
\text { and an ability to engage in life- } \\
\text { long learning }\end{array}$ & 3.67 & 0.71 & 5 & 3 & 4.25 & 1.04 & 5 & 2 \\
\hline $\begin{array}{l}\text { my knowledge of contemporary } \\
\text { issues }\end{array}$ & 4.00 & 0.71 & 5 & 3 & 4.00 & 0.76 & 5 & 3 \\
\hline $\begin{array}{l}\text { my ability to use the techniques, } \\
\text { skills, and modern engineering } \\
\text { tools necessary for engineering } \\
\text { practice }\end{array}$ & 3.67 & 0.50 & 4 & 3 & 4.25 & 0.71 & 5 & 3 \\
\hline
\end{tabular}


Table 2: Student Survey Responses related to ABET Outcomes (Spring 2008)

\begin{tabular}{|c|c|c|c|c|c|c|c|c|}
\hline Course & $\begin{array}{l}\text { Stren } \\
\text { ESC }\end{array}$ & gth of & Materi & & $\begin{array}{l}\text { Cons } \\
\text { and } 1\end{array}$ & uction & $\begin{array}{l}\text { Plann } \\
\text { gg CV }\end{array}$ & $\begin{array}{ll}\text { ng } \\
\text { E } 403\end{array}$ \\
\hline The case studies contributed to: & Ave & SD & High & Low & Ave & SD & High & Low \\
\hline $\begin{array}{l}\text { my ability to apply knowledge of } \\
\text { mathematics, science, and } \\
\text { engineering; }\end{array}$ & 3.89 & 0.89 & 5 & 2 & 3.81 & 0.54 & 5 & 3 \\
\hline $\begin{array}{l}\text { my ability to design and conduct } \\
\text { experiments, as well as to analyze } \\
\text { and interpret data }\end{array}$ & 3.56 & 0.75 & 5 & 2 & 3.81 & 0.40 & 4 & 3 \\
\hline $\begin{array}{l}\text { my ability to design a system, } \\
\text { component, or process to meet } \\
\text { desired needs, using the principles } \\
\text { of equilibrium; }\end{array}$ & 3.80 & 0.87 & 5 & 2 & 3.94 & 0.77 & 5 & 3 \\
\hline $\begin{array}{l}\text { my ability to function on multi- } \\
\text { disciplinary teams }\end{array}$ & 3.54 & 0.98 & 5 & 1 & 3.50 & 0.82 & 5 & 2 \\
\hline $\begin{array}{l}\text { my ability to identify, formulate, } \\
\text { and solve engineering problems; }\end{array}$ & 4.19 & 0.57 & 5 & 3 & 3.88 & 0.72 & 5 & 3 \\
\hline $\begin{array}{l}\text { my understanding of professional } \\
\text { and ethical responsibility }\end{array}$ & 4.52 & 0.70 & 5 & 3 & 4.88 & 0.34 & 5 & 4 \\
\hline $\begin{array}{l}\text { my ability to communicate my } \\
\text { problem solutions effectively; }\end{array}$ & 3.85 & 0.91 & 5 & 2 & 4.00 & 0.73 & 5 & 3 \\
\hline $\begin{array}{l}\text { the broad education necessary to } \\
\text { understand the impact of } \\
\text { engineering solutions in a global } \\
\text { and social context }\end{array}$ & 4.08 & 0.74 & 5 & 3 & 4.38 & 0.62 & 5 & 3 \\
\hline $\begin{array}{l}\text { my recognition of the need for, } \\
\text { and an ability to engage in life- } \\
\text { long learning }\end{array}$ & 4.16 & 0.69 & 5 & 3 & 4.63 & 0.50 & 5 & 4 \\
\hline $\begin{array}{l}\text { my knowledge of contemporary } \\
\text { issues }\end{array}$ & 4.15 & 0.78 & 5 & 3 & 4.00 & 0.73 & 5 & 3 \\
\hline $\begin{array}{l}\text { my ability to use the techniques, } \\
\text { skills, and modern engineering } \\
\text { tools necessary for engineering } \\
\text { practice }\end{array}$ & 4.00 & 0.89 & 5 & 2 & 4.00 & 0.63 & 5 & 3 \\
\hline
\end{tabular}


Table 3: Student Survey Responses on Relative Contributions to Interest and Understanding of the Course Material (Spring 2007)

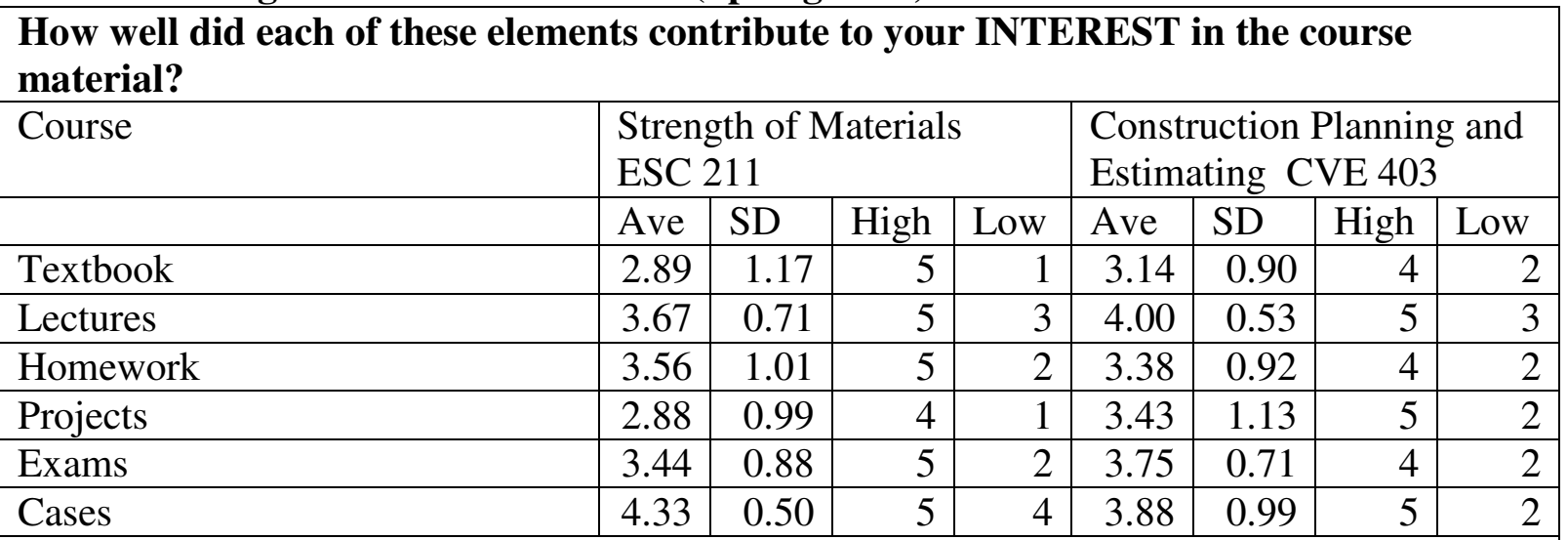

How well did each of these elements contribute to your UNDERSTANDING of the course material?

\begin{tabular}{|l|r|r|r|r|r|r|r|r|}
\hline Textbook & 3.78 & 1.20 & 5 & 1 & 3.14 & 0.69 & 4 & 2 \\
\hline Lectures & 4.00 & 1.00 & 5 & 2 & 3.50 & 0.93 & 5 & 2 \\
\hline Homework & 4.11 & 1.05 & 5 & 2 & 3.75 & 0.89 & 5 & 2 \\
\hline Projects & 2.56 & 1.01 & 4 & 1 & 3.29 & 0.95 & 4 & 2 \\
\hline Exams & 4.22 & 0.67 & 5 & 3 & 3.88 & 0.99 & 5 & 2 \\
\hline Cases & 4.00 & 1.00 & 5 & 2 & 4.00 & 0.93 & 5 & 2 \\
\hline
\end{tabular}

Table 4: Student Survey Responses on Relative Contributions to Interest and Understanding of the Course Material (Spring 2008)

How well did each of these elements contribute to your INTEREST in the course material?

\begin{tabular}{|c|c|c|c|c|c|c|c|c|}
\hline \multirow[t]{2}{*}{ Course } & \multicolumn{4}{|c|}{$\begin{array}{l}\text { Strength of Materials } \\
\text { ESC } 211\end{array}$} & \multicolumn{4}{|c|}{$\begin{array}{l}\text { Construction Planning and } \\
\text { Estimating CVE } 403\end{array}$} \\
\hline & Ave & $\mathrm{SD}$ & High & Low & Ave & $\mathrm{SD}$ & High & Low \\
\hline Textbook & 3.00 & 1.13 & 5 & 1 & 3.00 & 1.00 & 4 & 1 \\
\hline Lectures & 3.92 & 0.84 & 5 & 3 & 4.38 & 0.96 & 5 & 2 \\
\hline Homework & 3.69 & 0.88 & 5 & 1 & 3.50 & 0.63 & 5 & 3 \\
\hline Projects & 3.26 & 0.92 & 5 & 1 & 3.15 & 0.90 & 4 & 1 \\
\hline Exams & 3.42 & 1.06 & 5 & 2 & 3.56 & 0.73 & 5 & 3 \\
\hline Cases & 4.04 & 0.87 & 5 & 2 & 4.50 & 0.63 & 5 & 3 \\
\hline
\end{tabular}

How well did each of these elements contribute to your UNDERSTANDING of the course material?

\begin{tabular}{|l|r|r|r|r|r|r|r|r|}
\hline Textbook & 3.54 & 1.07 & 5 & 1 & 3.18 & 1.17 & 5 & 1 \\
\hline Lectures & 4.08 & 0.74 & 5 & 3 & 4.50 & 0.89 & 5 & 2 \\
\hline Homework & 4.00 & 0.85 & 5 & 2 & 4.13 & 0.81 & 5 & 2 \\
\hline Projects & 3.09 & 0.95 & 5 & 1 & 3.18 & 1.54 & 5 & 1 \\
\hline Exams & 3.54 & 1.14 & 5 & 2 & 3.88 & 0.72 & 5 & 3 \\
\hline Cases & 3.73 & 0.87 & 5 & 2 & 4.50 & 0.63 & 5 & 3 \\
\hline
\end{tabular}


The focus groups identified additional benefits to the use of case studies. The sophomore students observed that the cases helped build engineering identity, and provided historical understanding. The cases made the technical information relevant and linked theory to practice. Also, the students remembered a lot about the case studies, including names, dates, and technical details about the failures. Further details are reported elsewhere ${ }^{2}$.

\section{New Textbook}

The new book with approximately 40 case studies is arranged into chapters by course topics. A chapter listing is shown in table 5. The book is discussed more thoroughly elsewhere ${ }^{7}$. Because this book is closely paralleled by the project web site, the web site is discussed in more detail.

Table 5: List of Chapters

\begin{tabular}{|l|l|}
\hline Chapter & Title \\
\hline 1 & Why Case Studies? \\
\hline 2 & Statics and Dynamics \\
\hline 3 & Mechanics of Materials \\
\hline 4 & Structural Analysis \\
\hline 5 & Reinforced Concrete Structures \\
\hline 6 & Steel Structures \\
\hline 7 & Soil Mechanics, Geotechnical Engineering, and Foundations \\
\hline 8 & Fluid Mechanics and Hydraulics \\
\hline 9 & Construction Materials \\
\hline 10 & Management, Ethics, and Professional Issues \\
\hline
\end{tabular}

\section{Project Web Site}

The project web site was prepared along with the book. The home page is shown in figure 1. Some of the web site's sections are shown in figure 2. The web site includes a master bibliography, a discussion of the faculty case study workshops, a chronological listing of case studies, a list of course pages, and information for faculty. 


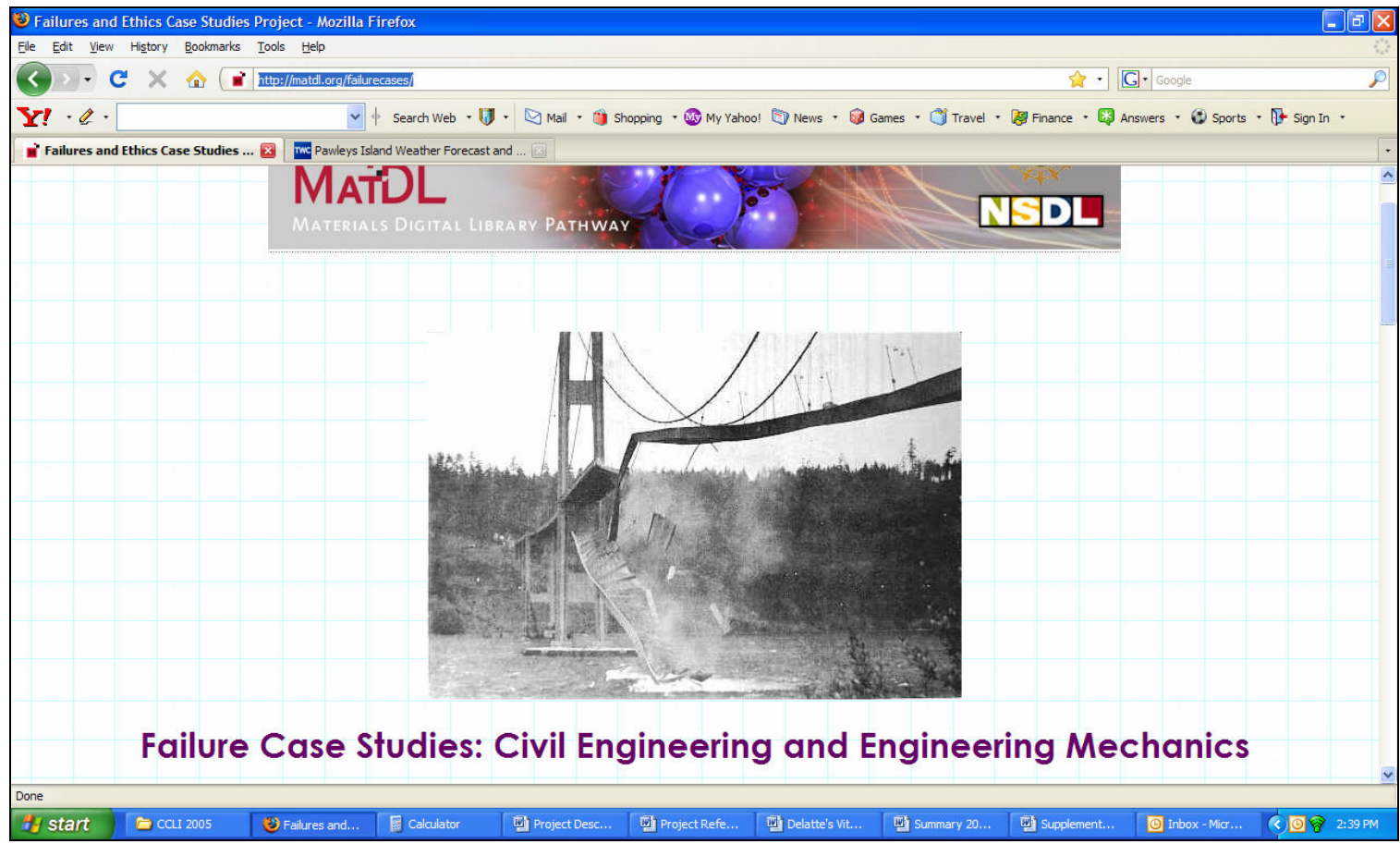

Figure 1: The Failure Case Studies web site home page, http://matdl.org/failurecases/

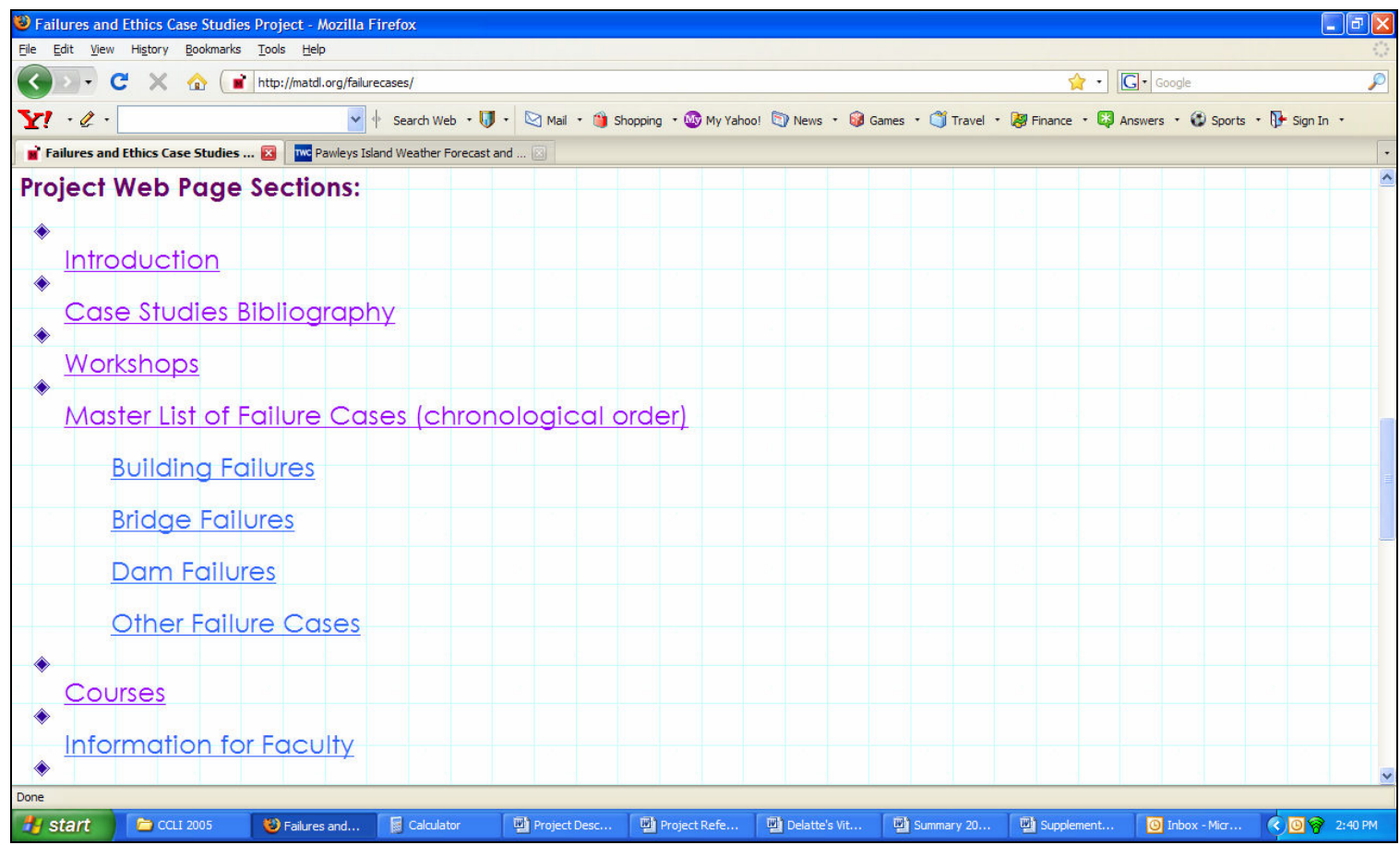

Figure 2: Sections of the web site

The listing of case studies is shown in figure 3, in chronological order. This list is also subdivided into building, bridge, dam, and other case studies. 


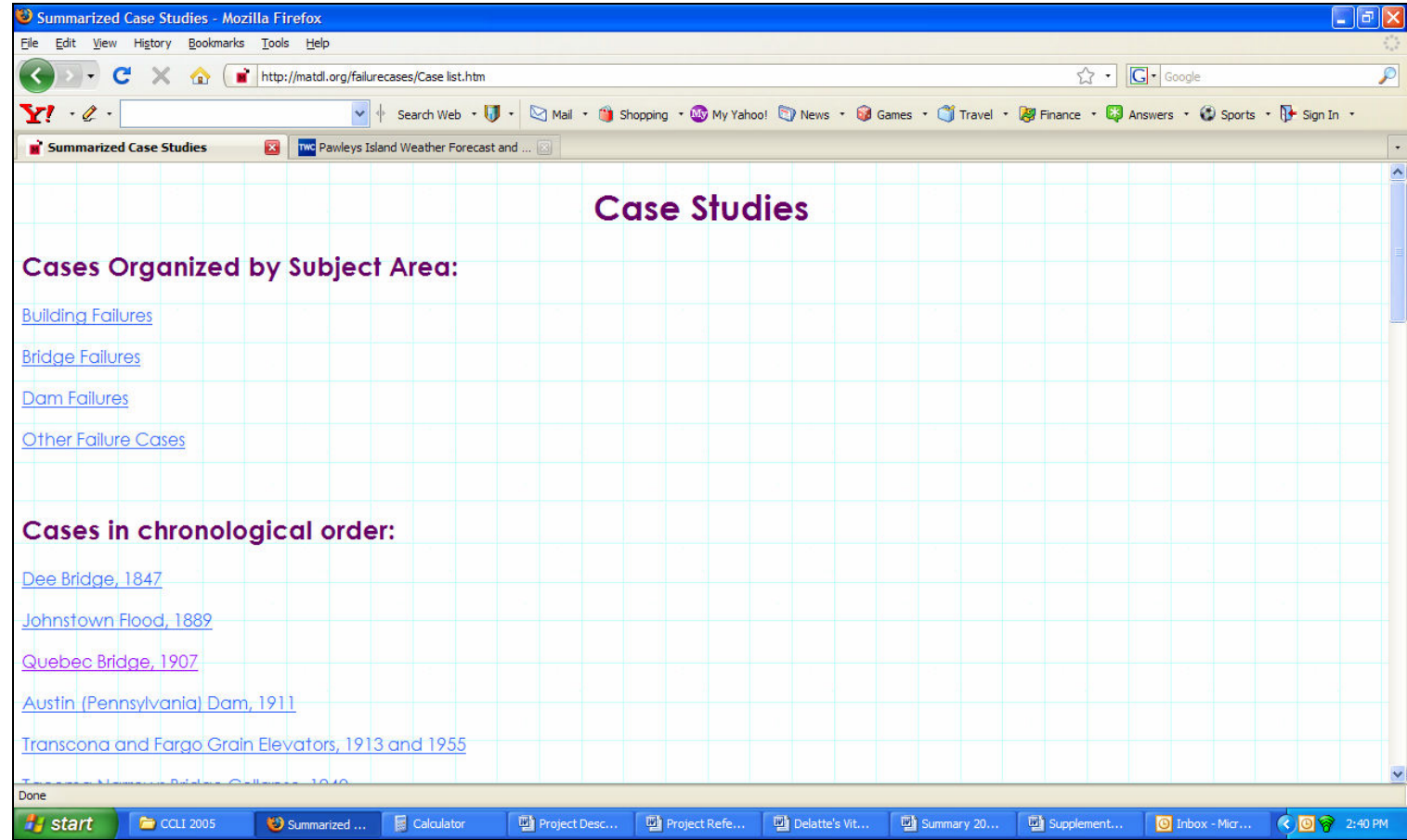

Figure 3: List of case studies in chronological order

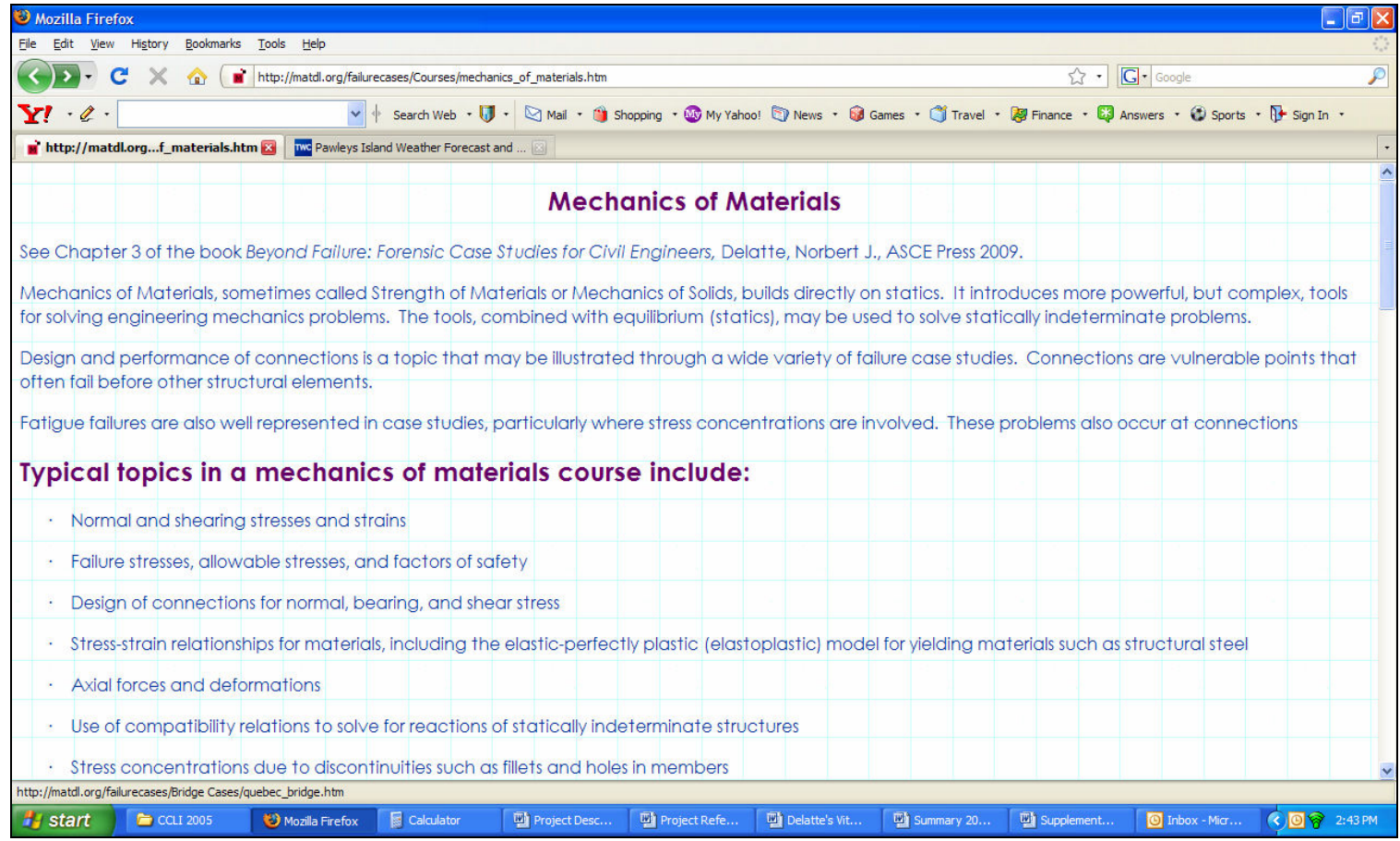

Figure 4: Sample course page, Mechanics of Materials:

A sample course page is shown in figure 4. This course page, for Mechanics of Materials, links to cases from the Master Course List (figure 3), including the case of the 1907 
Quebec Bridge Collapse (figure 5). Many of the cases, such as Quebec Bridge, can be used in many different courses and thus show up on several web pages.

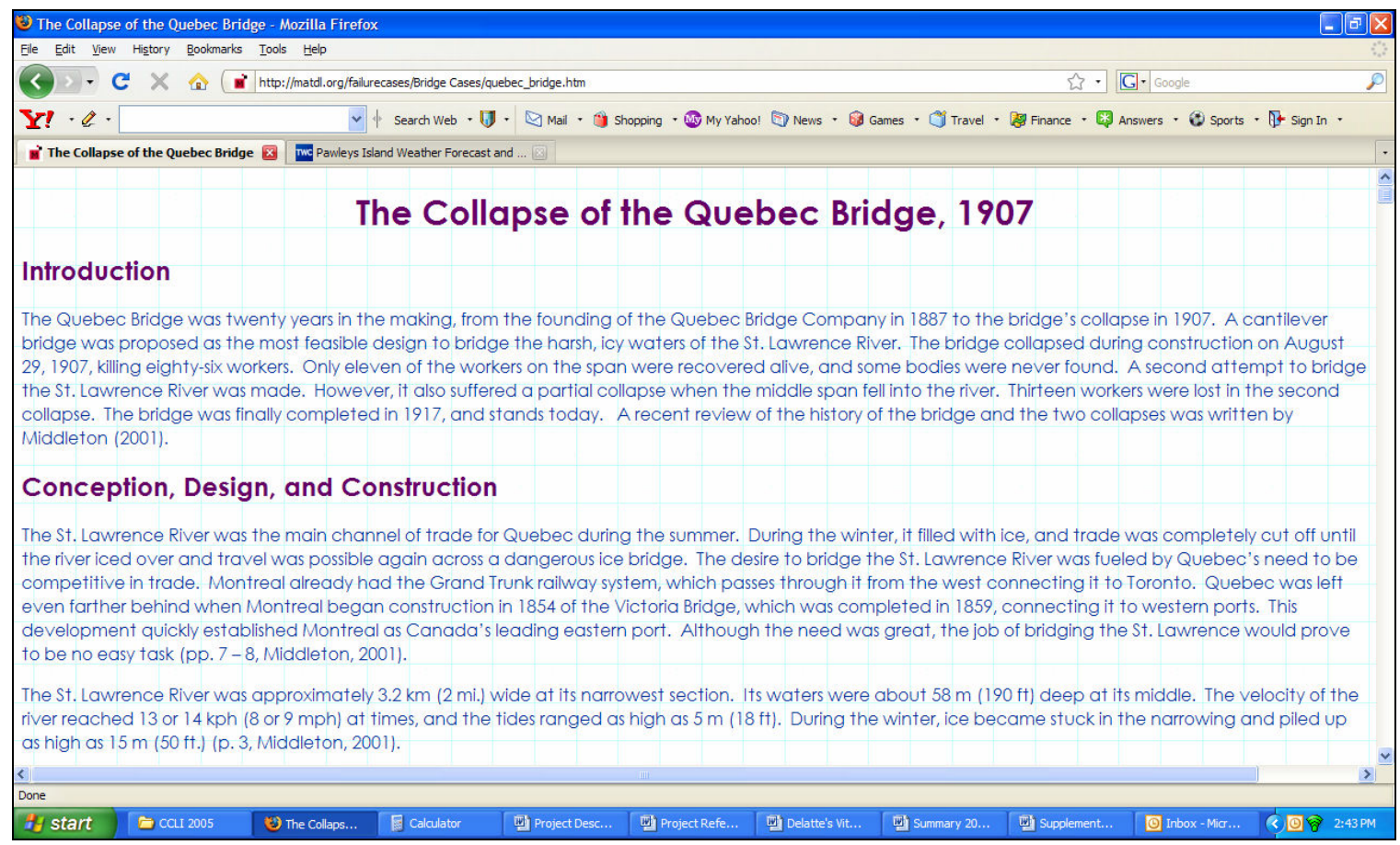

Figure 5: Sample case study page: Quebec Bridge

The web site is not merely a web version of the book. The book has more detail about many of the cases. There are also short cases on the web site which are not in the book. The two are intended to complement each other.

\section{Summary and Conclusions}

The assessment instruments and processes developed during the project have yielded useful results. The students enjoyed the case studies and believed that they contributed to learning the course material. The case studies stimulated their interest.

Most faculty who had participated in the one-day case study workshop and who responded to the survey had made at least some use of the cases in their courses. Although the range of responses was wide, responses indicated:

- It was not particularly difficult to include case studies in courses

- The workshop materials were helpful

- A significant time commitment was often needed to incorporate case studies

- Usefulness to students was high

All fourteen respondents that had used case studies believed that the benefits justified the cost. A number of them requested additional case study materials. 


\section{Acknowledgement:}

This work was sponsored by the grant "Assessing the Impact of Case Studies on the Civil Engineering and Engineering Mechanics Curriculum," National Science Foundation Project DUE-0536666, \$ 125,000, July 1, 2006 - June 30, 2009, program officer Russell L. Pimmel. Opinions expressed are solely those of the authors and not of the National Science Foundation

\section{Bibliographic Information:}

${ }^{1}$ Norb Delatte, Rosemary Sutton, William Beasley, and Joshua Bagaka's, “Assessing the Impact of Case Studies on the Civil Engineering and Engineering Mechanics Curriculum," Proceedings of the 2007 American Society for Engineering Education Annual Conference \& Exposition, Honolulu, Hawaii, 24 - 27 June 2007.

2 Delatte, N. J. Bosela, P., Sutton, R., Beasley, W., and Bagaka's, J., "Assessing the Impact of Case Studies on the Civil Engineering and Engineering Mechanics Curriculum, Phase II," Proceedings of the 2008 American Society for Engineering Education Annual Conference \& Exposition, Pittsburgh, Pennsylvania, June 2008.

${ }^{3}$ Lessons from failure instigations: A resource for engineering education, by Ken Carper, Delatte, and Kevin Rens, International Conference on Forensic Engineering: Failure Diagnosis and Problem Solving, Mumbai, India, December 6-9, 2007

${ }^{4}$ Norbert J. Delatte, Paul A. Bosela, Rosemary Sutton, Joshua Bagaka's, Implementing Forensics and Failures in the Civil Engineering Curriculum, Proceedings of the Fourth International Conference on Forensic Engineering From Failure to Understanding, London, UK, December 2, 2008

${ }^{5}$ Norb Delatte, Paul Bosela, Kevin Rens, Kenneth Carper, and Kevin Sutterer, "Findings from Workshops on Failure Case Studies in the Civil Engineering and Engineering Mechanics Curriculum," Proceedings of the 2007 American Society for Engineering Education Annual Conference \& Exposition, Honolulu, Hawaii, 24 - 27 June 2007.

${ }^{6}$ Delatte, Norbert J., Beyond Failure: Forensic Case Studies for Civil Engineers, ASCE Press, 2009.

${ }^{7}$ Delatte, Norbert J., Failure Case Studies in the Civil Engineering and Engineering Mechanics Curriculum: A New Textbook, submitted for 2009 ASEE Annual Conference \& Exposition 